\title{
PRASASTI-PRASASTI SAPATHA SRIWIJAYA: KAJIAN PANOPTISISME FOUCAULT
}

\section{SAPATHA PRASASTIES OF SRIWIJAYA: STUDY OF FOUCAULT PANOPTISISM}

\author{
Nainunis Aulia Izza \\ Program Studi Arkeologi, Fakultas IImu Budaya, Universitas Jambi \\ nainunis@unja.ac.id
}

Naskah diterima: 15 Mei 2018; direvisi: 30 Mei 2019; disetujui: 20 Juni 2019

\begin{abstract}
ABSTRAK
Kajian ini dilakukan guna menelaah prasasti-prasasti sapatha Sriwijaya melalui perspektif panopticon Michel Foucault. Tujuannya adalah untuk menganalisis latar belakang pencantuman kutukan atau sapatha pada prasasti-prasasti tertua Sriwijaya dan hubungannya dengan pemikiran Foucault mengenai panoptisisme. Berdasarkan pembahasan yang telah dilakukan, pertama pencantuman sapatha pada prasasti-prasasti tertua Sriwijaya bertujuan sebagai upaya melakukan kontrol terhadap wilayah dan penduduk yang berada di wilayah Sriwijaya. Kedua, sapatha pada prasasti-prasasti tertua Sriwijaya dapat dikaitkan dengan upaya mempertahankan wilayah-wilayah strategis dengan menempatkan pihak-pihak yang dikuasai sebagai subjek yang selalu diintai sapatha jika melakukan kejahatan dan pengkhianatan.
\end{abstract}

Kata Kunci: Prasasti, Sriwijaya, Sapatha, Panoptisisme

Abstract

This study aims to discuss Sapatha on Sriwijaya Inscriptions from the panopticon perspective of Michel Foucault. This study aims to analyze the existence curse or sapatha on Sriwijaya's oldest inscriptions and its relation to panoptism from Foucault's thinking. This research identifies, first sapatha is tool to control over the territory and populace in the Sriwijaya region. Second, sapatha on Sriwijaya's oldest inscriptions can be related to best method to protect strategic areas by placing sapatha as spy for the rein subjects.

Keywords: Inscription, Sriwijaya, Sapatha, Panoptism.

\section{PENDAHULUAN}

Kata prasasti berasal dari Bahasa Sansekerta praśasti dapat diartikan sebagai sanjungan atau pujian dan dalam arti lain dapat berarti pedoman, pembimbing, maupun ancaman (Williams, 1964: 695). Arti kata prasasti yang dikenal sekarang, yaitu sumber tertulis yang memuat informasi mengenai peristiwa penting. Prasasti juga dapat diartikan sebagai sumber tertulis yang dibuat pada bahan yang awet atau tahan lama, misalnya batu, logam, kayu, maupun tulang binatang (Mardiana, 2015: 3). Prasasti tertua yang ditemukan di Nusantara adalah Prasasti Yūpa I sampai VII yang ditemukan di Kalimantan Timur dan berdasarkan bentuk aksaranya diperkirakan berasal dari abad ke-4 sampai 5 Masehi (Mardiana, 2016: 131144). Prasasti di Nusantara yang dibuat pada masa Hindu-Buddha memiliki ciri khas yang dapat dilihat dari jenis aksara 
maupun bahasa yang digunakan, media pahatan, ornamen yang menyertainya, serta isi dari prasasti yang berkaitan dengan bidang politik, sosial, agama, ekonomi, maupun aspek-aspek lain yang dapat memberikan gambaran mengenai kehidupan masyarakat pembuatnya.

Prasasti-prasasti tertua di Nusantara dapat memberikan gambaran mengenai kehidupan nenek moyang bangsa Indonesia sejak terpengaruh kebudayaan India. Prasasti Yūpa peninggalan Kerajaan Kutai Kuno dan prasasti-prasasti peninggalan Kerajaan Tarumanegara memiliki pola yang hampir serupa. Baik Prasasti Yūpa maupun prasasti dari Kerajaan Tarumanegara memuat pujian tentang pemimpin atau raja (Mardiana, 2015: 3). Pujian kepada pemimpin atau raja sebagai tokoh sentral yang termuat dalam prasasti sekaligus dapat diartikan sebagai wujud adanya kuasa terhadap suatu kerajaan atau suatu wilayah tempat prasasti tersebut diletakkan. Selain Kerajaan Kutai Kuno dan Tarumanegara yang pernah Berjaya sekitar abad ke 4 sampai 6 Masehi. Kerajaan tertua lain yang ada di Nusantara adalah Kerajaan Sriwijaya yang berdasarkan bukti tertulisnya pernah Berjaya mulai abad ke 7 Masehi.

Agaknya prasasti-prasasti dari masa Sriwijaya memiliki pola yang berbeda dengan prasasti dari Kerajaan Kutai Kuno dan Tarumanegara. Prasasti-prasasti masa Sriwijaya umumnya memuat kata-kata kutukan atau sapatha bagi pelanggar perintah penguasa Sriwijaya. Hal ini tidak terdapat pada prasasti-prasasti masa sebelumnya di Nusantara. Sebenarnya, adanya kata-kata kutukan pada prasasti juga tercantum pada prasasti dari masa yang lebih kemudian. Beberapa prasasti masa Mataram Kuno maupun Majapahit juga memuat kata kutukan bagi pelanggar isi prasasti, namun hal ini umumnya berlaku untuk daerah sima, sedangkan prasasti-prasasti masa Sriwijaya hanya beberapa yang membahas mengenai penetapan sima (Mardiana, 2015: 29). Mengenai kutukan atau sapatha ini menarik untuk dikaji dan dikaitkan dengan aspek kuasa raja, khususnya pada masa Sriwijaya yang memiliki kronologi lebih tua daripada Mataram Kuno maupun Majapahit.

Tulisan ini akan berfokus pada pembahasan mengenai unsur kutukan atau sapatha yang ada pada prasasti- 
prasasti tertua masa Sriwijaya. Pembahasan mengenai unsur kutukan akan dikaji dengan perspektif panoptisisme yang digagas oleh Jeremy Bentham dan kemudian diadopsi oleh Michel (Foucault, 1995: ix). Tujuannya adalah untuk mencoba menganalisis latar belakang pencantuman kutukan atau sapatha pada prasasti-prasasti tertua Sriwijaya dan hubungannya dengan pemikiran Foucault mengenai panoptisisme.

\section{PEMBAHASAN}

Michel Foucault dalam bukunya yang telah diterjemahkan dalam Bahasa Inggris berjudul Discipline and Punish: The Birth of the Prison secara rinci memaparkan pemikirannya mengenai perubahan metode hukuman. Hukuman di Eropa dan Amerika pada abad ke-17 sampai abad ke-19 bersifat hukuman fisik yang dipertontonkan kepada khalayak umum berangsur-angsur berubah menjad hukuman pendisiplinan. Hukuman fisik menurut Foucault adalah proses menghukum yang menyakitkan. Semakin besar kesalahan seseorang, maka semakin Panjang tahapan penyiksaan seseorang dan semakin menyakitkan pula proses terhukum sampai pada hukuman terberatnya, yaitu hukuman mati
(Foucault, 1995: 149-177). Sama halnya dengan yang pernah terjadi di Nusantara pada masa lalu, di Batavia (sekarag Jakarta) misalnya pada abad ke-18 Belanda melaksanakan hukumanhukuman fisik dimana para terhukum disiksa dan dieksekusi di pusat kota dan menjadi tontonan khalayak umum (Kanumoyoso, 2011: 50).

Hukuman fisik setidaknya memiliki dua tujuan utama, pertama sebagai wujud adanya kekuasaan pihak pemberi hukuman yang berhak menjatuhkan hukuman sesuai dengan kesalahan yang dibuat terhukum. Tujuan kedua adalah sebagai sarana membentuk pemikiran orang-orang yang melihat bahwa pemberi hukuman adalah pihak yang benar dan melaksanakan hukuman sesuai dengan aturan yang berlaku sementara orang yang dihukum adalah pihak yang salah dan pantas menerima hukuman. Efek lanjutannya diharapkan khayalak yang melihat jera dan tidak melakukan perbuatan melanggar aturan penguasa, jika melanggar fisik mereka akan disiksa sedemikian rupa (Foucault, 1995: 149-177).

Setelah abad ke-19 mulai muncul kesadaran atas kemanusiaan di Eropa dan Amerika. Hukuman yang 
sebelumnya bersifat hukuman fisik berangsur-angsur mulai diubah menjadi hukuman non fisik berupa pendisiplinan. Hukuman fisik menurut Foucault tidak seluruhnya hilang, namun direduksi sedemikian rupa sehingga para terhukum tidak lagi mendapatkan siksaan fisik. Hukuman yang diberikan lebih kepada pendisiplinan tubuh orang yang dihukum (Foucault, 1995: 22-30). Orang-orang yang bersalah tidak lagi diseret ke tempat umum dan hukumannya disaksikan khayalak, orang yang bersalah akan dikurung, didisiplinkan, dan diawasi.

Pemikiran baru mengenai konsep hukuman mempengaruhi bangunan penjara yang digunakan sebagai tempat pelaksanaan hukuman. Foucault menyoroti pendirian Panopticon, yaitu sebuah rancangan bangunan penjara yang digagas Jeremy Bentham. Penjara Panopticon yang dirancang pada tahun 1843 (Lihat Gambar 1) memunculkan konsep hukuman yang baru. Bangunan penjara dibangun dengan menempatkan sel-sel tahanan disekeliling halaman penjara dan di tengah halaman penjara dilengkapi dengan menara pengawas (Foucault, 1995: 200-201).. Bentuk rancang bangun seperti ini membuat tahanan yang sedang dikurung dan didisiplinkan tidak dapat mengamati penjaga di menara pengawas.

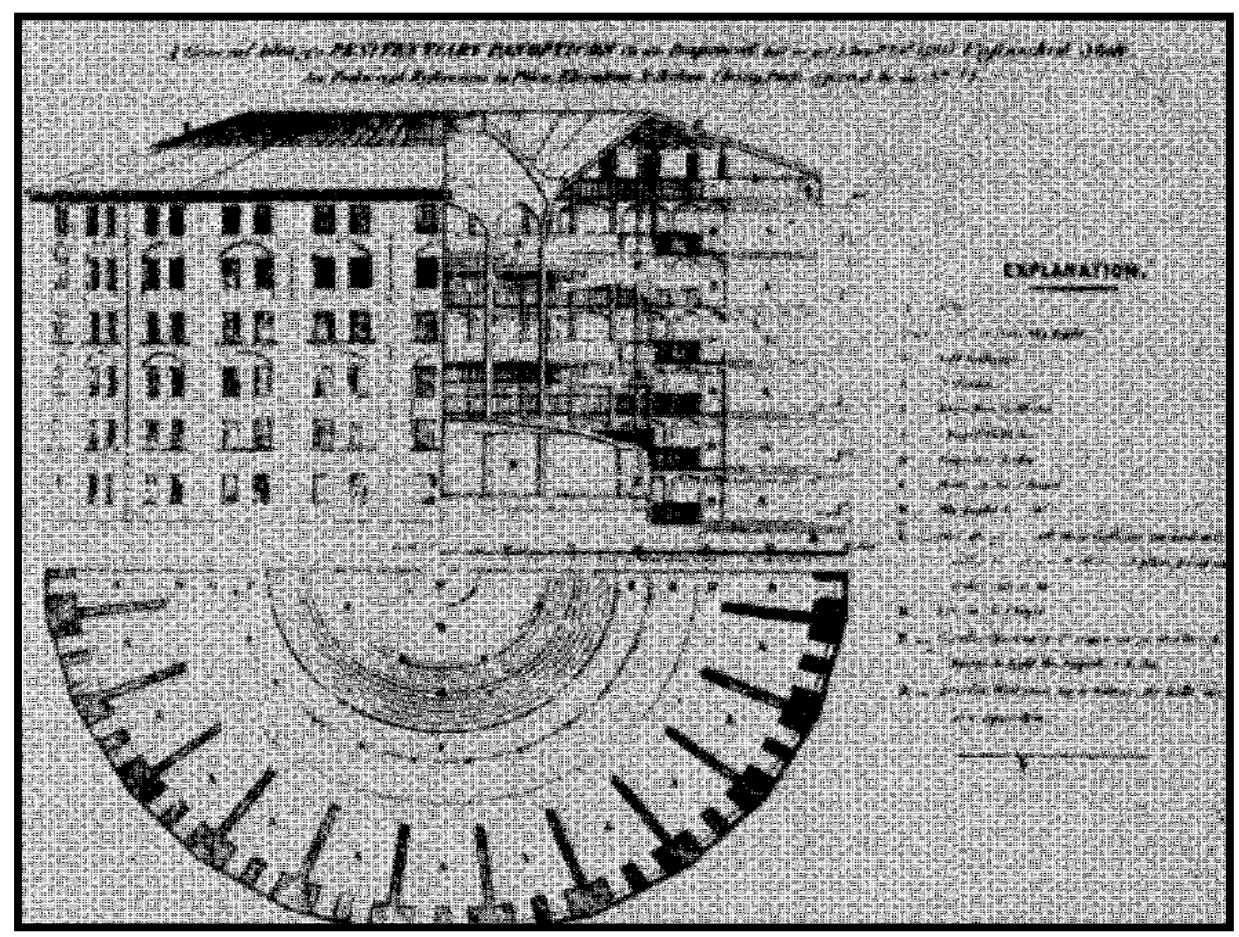




\section{Gambar 1. Rancangan Penjara Panopticon yang dibuat Jeremy Bentham (Foucault, 1995: tanpa halaman).}

Model pengawasan yang mirip seperti panopticon juga ada di Indonesia, yaitu gardu. Meskipun tidak berfungsi sebagai tempat pelaksanaan hukuman. Fungsi gardu mirip dengan menara pengawas di penjara panopticon. Abidin Kusno (2007) menulis buku yang membahas mengenai fungsi gardu sebagai wakil penguasa dan tempat untuk mengawasi kegiatan yang berada di sekitar bangunan. Pada umumnya gardu dibangun di tempat yang strategis seperti dekat gerbang perumahan atau persimpangan jalan yang memungkinkan pengawas dapat mengetahui orang-orang yang berlalu Lalang. Secara ringkas konsep gardu dari masa ke masa adalah sebagai tempat untuk mengawasi kegiatan di sekitarnya.

\section{Bangunan penjara panopticon} disatu sisi menyebabkan para tahanan selalu merasa diawasi dan harus senantiasa waspada dan disisi lain seorang pengawas yang berada di menara dapat mengawasi seluruh tahanan yang ada dengan cara yang lebih efektif. Konsep hukuman semacam ini menunjukkan cara yang lebih sederhana dalam upaya pengawasan, maksudnya baik ketika ada pengawas maupun tidak atau berapapun jumlah pengawas yang ada, menara tetap menjadi simbol pengawasan. Pengawas dan menara yang ada di penjara dapat dianalogikan sebagai wakil penguasa sedangkan tahanan akan merasa selalu diawasi setiap detiknya ketika menara tersebut masih berdiri (Foucault, 1995: 200201).

Pada penelitian ini penulis mencoba menganalisis panoptisisme sesuai dengan pemikiran Michel Foucault dalam bukunya Discipline and Punish: The Birth of the Prison. Pemikiran Foucault mengenai panoptisisme digunakan sebagai alat untuk menganalisis isi serta latar belakang penempatan prasasti-prasasti yang mencantumkan sapatha dari masa Sriwijaya.

Sriwijaya dewasa ini dikenal sebagai sebuah kerajaan masa HinduBuddha di Nusantara yang pernah berjaya dan memiliki wilayah yang luas di sekitar Semenanjung Melayu. Bahkan Muhammad Yamin (dalam Hardinanto, 2017: 54) pada sidang 
Badan Penyelidik Usana-usaha Persiapan Kemerdekaan Indonesia (BPUPKI) pernah menyebutkan Sriwijaya sebagai negeri pendahulu Indonesia. Kebesaran Sriwijaya juga dapat dibuktikan dengan adanya informasi dari kronik Cina dan tinggalan-tinggalan Arkeologis yang berada di sekitar Semenanjung Melayu terutama Pulau Sumatra (Hardiati dkk, 2010: 67-70). Sayangnya, hingga saat ini belum diketahui secara pasti lokasi ibukota dan batas-batas wilayah Kerajaan Sriwijaya. Roy-William Bottenberg (2010: 15) dalam tesisnya bahkan menyangsikan kerajaan bernama Sriwijaya sebagai mitos atau realitas. Berkaitan dengan kekuasaan Sriwijaya, pada subbab ini akan dipaparkan prasasti-prasasti yang berhubungan dengan Sriwijaya.

\section{Prasasti-prasasti} yang berhubungan dengan Sriwijaya antara lain adalah Prasasti Kedukan Bukit, Prasasti Talang Tuwo, Prasasti Kota Kapur, Prasasti Ligor, Prasasti Palas Pasemah, Prasasti Telaga Batu, Prasasti Karang Berahi, Prasasti Leiden, Prasasti Bukit Siguntang, Prasasti Siddhayatra, Prasasti Boom Baru, Prasasti Kambang Purun, Prasasti Sabokingking, Prasasti Palas Pasemah, Prasasti Bungkuk
(Jabung), Prasasti Batu Bedil, Prasasti Hujung Langit (Bawang), Prasasti Tanjung Raya I dan II, Prasasti Ulu Belu, Prasasti Dadak, Prasasti Angka Tahun Pugung Raharjo, dan Prasasti Baturaja (Kartakusuma, 1993: 17; Taim, 2013: 102; Utomo, 2010: 68). Sesuai dengan pembahasan mengenai pencantuman kutukan atau sapatha pada prasasti-prasasti tertua Sriwijaya dan hubungannya dengan pemikiran Foucault mengenai panoptisisme, maka yang dibahas lebih lanjut dalam tulisan ini hanya beberapa yang memuat unsur kutukan atau sapatha yang kronologiya sekitar abad ke-7 masehi.

Pertama, adalah Prasasti Kota Kapur yang ditemukan di Bangka. Prasasti Kota Kapur berbentuk obelisk dan ditemukan bersama struktur bangunan dan arca-arca Dewa Wisnu. Huruf yang dipahatkan adalah Pallawa dan menggunakan Bahasa Melayu Kuno. Pertanggalan prasasti menunjukkan tahun 608 Śaka (686 Masehi). Isi prasasti antara lain memuat mengenai ancaman kematian karena kutukan bagi orang-orang yang memberontak atau bersekongkol dengan pemberontak serta orang-orang yang tidak takhluk pada penguasa Sriwijaya serta harapan tentang berkah, kesehatan, 
dan hal-hal positif lain kepada pihakpihak yang setia kepada penguasa (Kern, 1913: 393-400).

Prasasti kedua adalah Prasasti Karang Brahi yang ditemukan di sekitar Batang Merangin, Desa Pamenang, Kecamatan Merangin, Kabupaten Jambi. Bidang pahatnya berupa batu dan aksaranya Pallawa serta berbahasa Melayu Kuno. Informasi mengenai prasasti ini pertama kali diperoleh dari Berkhout tahun 1904. Prasasti ini tidak mengandung unsur penanggalan, namun berdasarkan bentuk huruf-hurufnya diperkirakan tidak terpaut jauh dari prasasti-prasasti lain masa Sriwijaya, yaitu sekitar abad ke-7 atau 8 masehi. Isi Prasasti Karang Berahi antara lain memuat sapatha, isinya antara lain ancaman kepada musuh-musuh Sriwijaya di dalam wilayah kekuasaan (dalam negeri) beserta uraian tentang kejadian-kejadian buruk dan kematian karena kutukan kepada pihak-pihak yang tidak tunduk kepada Sriwijaya (Hardiati dkk, 2010: 79).
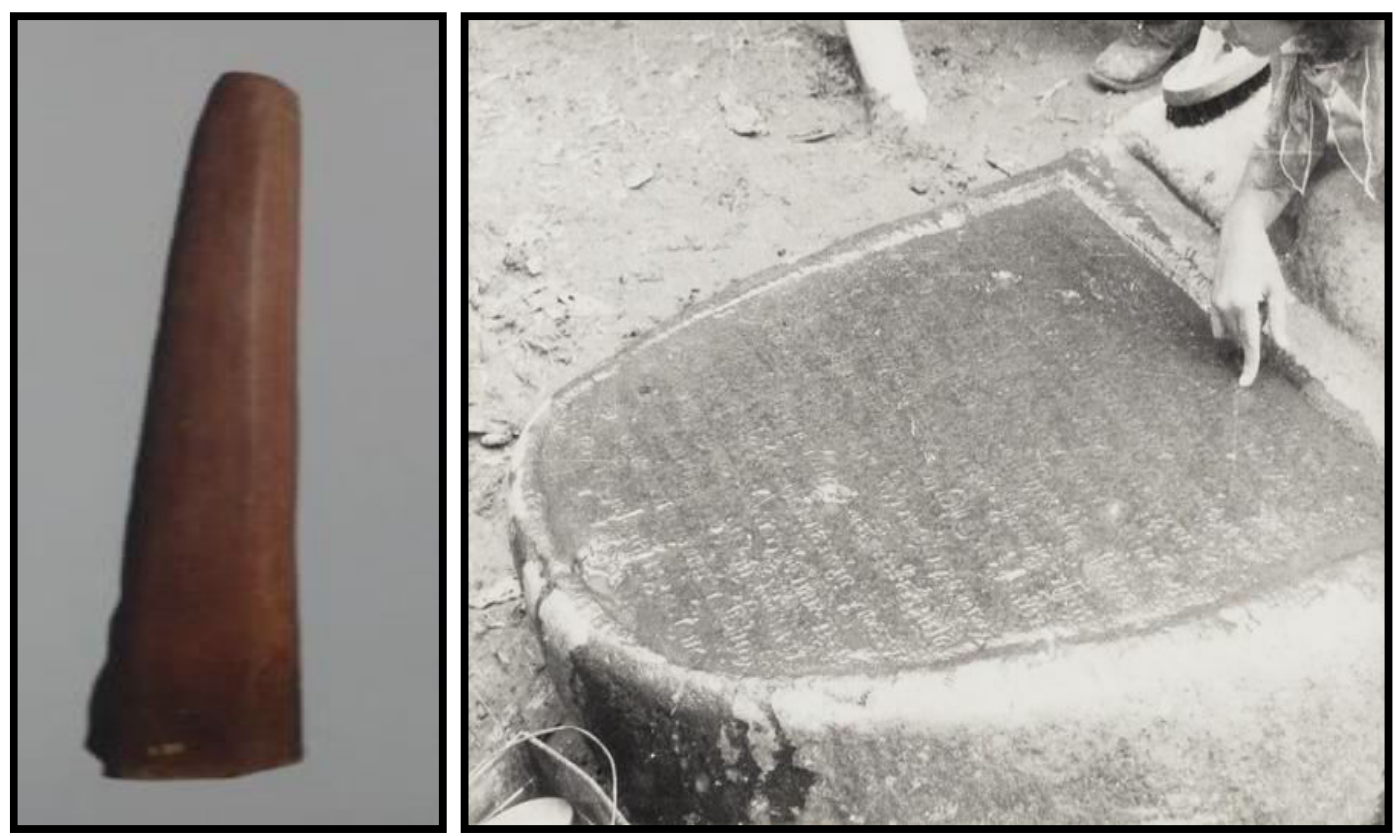

Foto 1 dan 2. Prasasti Kota Kapur (kiri) dan Prasasti Karang Brahi (kanan) (Sumber: Mardiana, 2016: 59; www.digitalcollections.universiteitleiden.nl)

Selanjutnya ada Prasasti Telaga

Batu yang sekarang disimpan di Museum Nasional dengan kode D.155. Prasasti Telaga Batu dipahatkan pada batu dan pada bagian atas diberi ukuran 7 (tujuh) kepala ular kobra dan pada bagian bawahnya bercerat seperti yoni. Prasasti Telaga Batu ditemukan di 
sekitar Palembang dan tidak memuat angka tahun. Berdasarkan jenis aksara Pallawa dan Bahasa Melayu Kuno yang dipakai, diperkirakan Prasasti ini semasa dengan Prasasti Kota Kapur dan Karang Brahi. Prasasti ini berisi tentang sumpah kesetiaan beberapa orang yang ada di struktur pemerintahan Sriwijaya serta ancaman atau sapatha yang akan menimpa jika melanggar sumpah tersebut (Kartakusuma, 1993: 18-23).

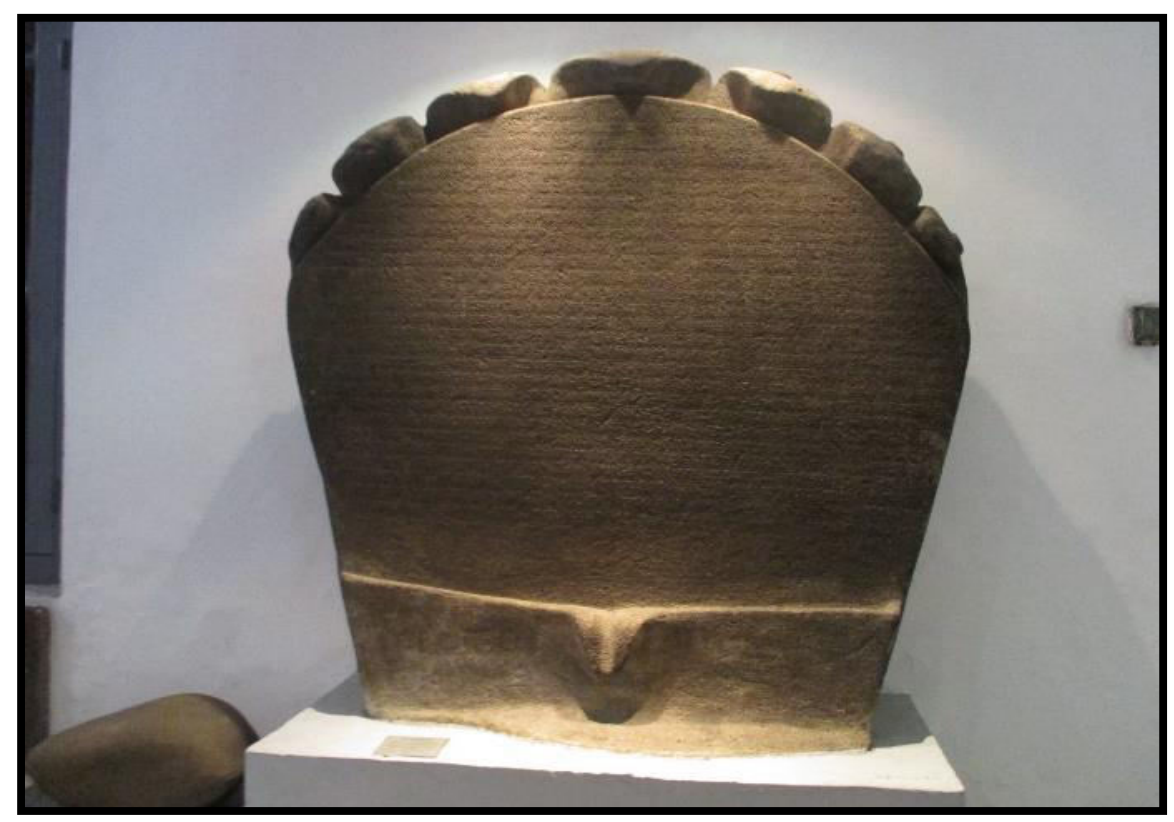

Foto 3. Prasasti Telaga Batu (Sumber: Dokumentasi Nainunis Aulia Izza, 2017).

Prasasti keempat adalah Prasasti

Palas Pasemah yang ditemukan di Desa

Palas, Kabupaten Lampung Selatan.

Prasasti ini ditemukan dalam keadaan

setengah terkubur pada tumaliatau batu nisan. Prasasti Palas Pasemah tidak berangka tahun, namun berdasarkan paleografi aksara Pallawa dan Bahasa Melayu Kuno menunjukkan gaya tulis abad ke-7 sampai 8 masehi. Pahatan prasasti Palas Pasemah Sudha aus dan secara umum isinya memuat tentang sapatha atau peringatan kutukan kepada pihak yang melakukan kejahatan dan berkhianat pada Sriwijaya (Utomo, 2010: 68).

$$
\text { Prasasti kelima dalam }
$$
pembahasan ini atau prasasti kedua yang berasal dari daerah Lampung adalah Prasasti Jabung (Bungkuk). Prasasti ini ditemukan tahun 1985. Mirip dengan Prasasti Palas Pasemah, kedua prasasti ini diperkirakan berasal dari kurun waktu yang hampir sama. 


\begin{abstract}
Aksara Pallawa pada Prasasti Bungkuk sudah aus dan secara garis besar isinya mengenai sumpah dan kutukan bagi pihak yang melakukan kejahatan pada Sriwijaya (Utomo, 2010: 68).
\end{abstract}

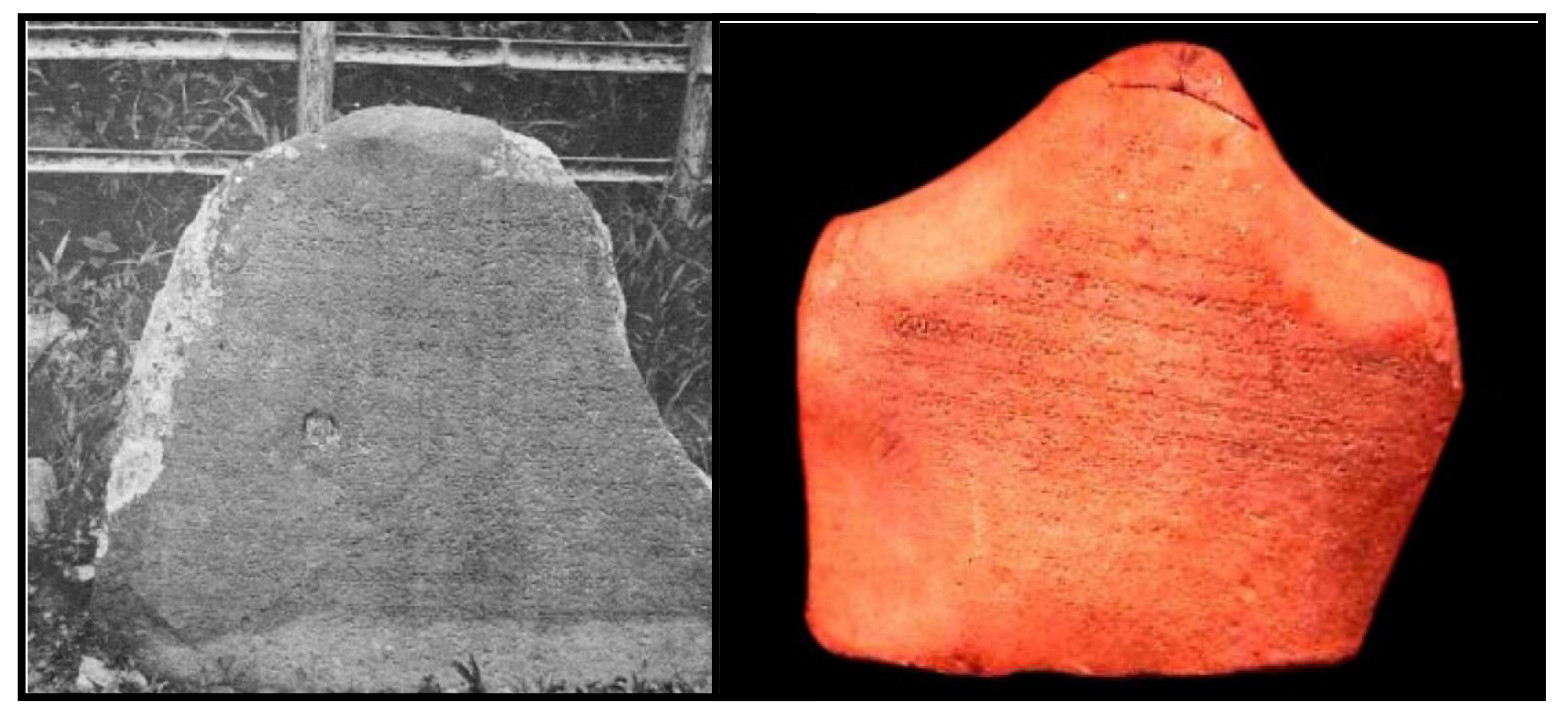

\title{
Foto 4 dan 5. Prasasti Palas Pasemah (kiri) dan Prasasti Jabung (Bungkuk) (kanan) (Sumber: Utomo, 2010: 68).
}

\begin{abstract}
Berdasarkan uraian kelima prasasti Sriwijaya yang dilengkapi dengan sapatha terdapat setidaknya 2 kesamaan. Pertama, dari segi aksara dan bahasa, kelima prasasti menggunakan Aksara Pallawa dan Bahasa Melayu Kuno. Hal ini sesuai dengan klasifikasi yang dilakukan oleh Richadiana Kartakusuma (1993: 25) yang menyebutkan prasasti-prasasti politik dari masa Sriwijaya seluruhnya menggunakan Bahasa Melayu Kuno, sedangkan prasasti-prasasti keagaamaan menggunakan Bahasa Sansekerta.
\end{abstract}

Kedua, mengenai isi sapatha kelima prasasti tersebut memiliki pola yang sama, yaitu ancaman kematian kepada pihak yang berbuat kejahatan serta pihak yang tidak setia kepada Sriwijaya. Uniknya ancaman ini tidak memuat unsur hukuman fisik atau denda seperti yang lazim tercantum pada prasastiprasasti sima, namun mentikberatkan pada ancaman kutukan yang berujung pada kematian sang pelanggar (Mardiana, 2015: 26-27). Perbedaan kelima prasasti tersebut terlihat pada letak asalnya yang menyebar di wilayah 
tengah dan selatan Pulau Sumatra. Hal ini sekaligus mengindikasikan luasnya kekuasaan Sriwijaya di Sumatra sekitar abad ke-7 sampai 8 masehi.

Antara prasasti-prasasti tertua Sriwijaya yang dilengkapi sapatha dengan menara penjara panopticon agaknya memiliki fungsi serupa. Baik prasasti maupun menara penjara dapat diartikan sebagai objek 'pengontrol'. Keberadaan fisik prasasti ini adalah sebagai bentuk nyata adanya kontrol atas penguasa Sriwijaya terhadap pihakpihak yang berada pada wilayah kekuasaan Sriwijaya. Keberadaan Prasasti Telaga Batu misalnya, uraian mengenai komponen-komponen kerajaan yang berada di bawah 'kontrol' menunjukkan fungsi prasasti tersebut sebagai objek pengontrol kesetiaan.

Kelima prasasti yang telah diuraiakan di atas dapat dipandang sebagai dokumen politik dan keagamaan yang setiap saat mengintai pihak-pihak yang tidak setia kepada kekuasaan Sriwijaya. Mengenai ancaman yang diberikan, prasasti-rasasti masa Sriwijaya menjabarkan konsekuensi atas dilanggarnya sapatha tidak berbentuk hukuman fisik yang dilakukan oleh penguasa Sriwijaya melainkan hukuman kutukan. Hal ini serupa dengan peran penjara yang menjadi media pendisiplinan tubuh dan bukan sebagai sarana pelaksanaan hukuman fisik dari pihak penguasa kepada pihak yang terhukum seperti yang pernah terjadi di Eropa dan Amerika pada abad ke-17 sampai 19 (Foucault, 1995: 177).

Sama halnya dengan menara penjara panopticon, kelima prasasti tersebut memiliki fungsi panoptisisme untuk mengintai pihak-pihak yang berada di suatu wilayah. Menara penjara yang berisikan penjaga tahanan dapat diartikan sebagai wakil penguasa yang memiliki wewenang untuk menindak dan mendisiplinkan perilaku para tahanan dalam sel. Sejalan dengan konsep tersebut kelima prasasti berisi sapatha juga dapat diartikan sebagai wakil penguasa Sriwijaya yang memiliki kekuatan untuk menindak (yang dalam hal ini menjatuhkan kutukan) dan mendisiplinkan para pelaku kejahatan dan pihak-pihak yang berkhianat pada Sriwijaya. Isi prasasti berupa ancaman kutukan yang akan menimpa pihak-pihak yang berbuat jahat dan atau berkhianat kepada Sriwijaya. Hal ini menempatkan penguasa Sriwijaya sebagai pihak yang berhak mengatur masyarakat dan 
anggota masyarakat yang melanggar perintah penguasa akan menjadi pihak yang patut disalahkan dan mendapat hukuman. Hukuman yang dimaksud adalah hukuman dari superhuman beings atau dewata yang Namanya disebut dalam teks prasasti.

Berdasarkan letak asal prasastinya, seperti yang telah disinggung pada subbab sebelumnya, kelima prasasti yang dibahas berada pada lokasi yang berbeda. Pertimbangan pemilihan lokasi ini pernah dibahas oleh Leornard Y. Andaya (2001: 320). Berdasarkan analisisnya, prasastiprasasti Sriwijaya diletakkan pada lokasi-lokasi yang strategis untuk mendukung pertahanan politik dan ekonomi Sriwijaya. Tersebarnya lokasi peletakkan prasasti ini juga dapat dihubungkan dengan bentuk pemerintahan Sriwijaya yang berupa Thalasokrasi atau kemaharajaan laut yang kekuatan ekonomi utamanya adalah perdagangan. Sebagai sebuah negeri yang wilayah lautnya lebih luas daripada wilayah daratnya, tentunya Sriwijaya memerlukan 'objek' untuk mempertahankan wilayahnya (Izza, 2015: 36-45).

Pertimbangan pemilihan lokasi peletakkan Prasasti Kota Kapur dapat dikorelasikan dengan letaknya yang berada di pantai timur Sumatra. Keletakan ini sangat strategis dari segi perdagangan dan untuk memajukan wilayah tersebut, penguasa Sriwijaya merasa perlu mengawasi kesetiaan penduduk di Pulau Bangka melalui sapatha pada Prasasti Kota Kapur. Penempatan Prasasti Karang Brahi, dapat dihubungkan dengan letaknya di hulu Batanghari yang merupakan pelabuhan sungai yang menghubungkan perdagangan antara dataran tinggi dan dataran rendah di Sumatra tengah dan barat (Andaya, 2001: 320). Prasasti Karang Berahi ditempatkan di dekat Batang Merangin yang secara khusus diperkirakan sebagai jalur perdagangan yang strategis.

$$
\text { Prasasti Telaga Batu yang }
$$
berada di wilayah Palembang saat ini juga dipilih karena lokasinya strategis. Penyebutan tokoh-tokoh masyarakat yang tidak ditemukan pada empat prasasti lain menunjukkan upaya penguasa Sriwijaya bukan hanya melindungi wilayah yang strategis namun juga untuk mengontrol tokoh masyarakat agar tunduk pada penguasa Sriwijaya. Kuat dugaan Prasasti Telaga Batu terletak di salah satu kantong 
kekuatan politik dan ekonomi pada masanya.

Mengenai pemilihan lokasi penempatan Prasasti Palas Pasemah dan Bungkuk di Lampung, dapat dikaitkan dengan lokasinya yang dekat dengan selat Sumatra dan Pulau Jawa. Wilayah ini perlu dikontrol karena merupakan wilayah penting bagi pertahanan ekonomi dan politik Sriwijaya. Berdasarkan pembahasan mengenai latar pemilihan letak, hasil analisis menunjukkan kelima prasasti sapatha dari masa Sriwijaya ditempatkan pada lokasi-lokasi yang strategis dalam bidang perdagangan sekaligus rawan melepaskan diri dari kekuasaan Sriwijaya. Hal ini sejalan dengan panotisisme yang menempatkan objek kontrol pada lokasi yang strategis. Pemilihan letak menara penjara Panopticon di tengah-tengah sel tahanan dapat dihubungkan dengan fungsinya sebagai objek pengontrol sel tahanan di sekitarnya. Jika menara penjara Panopticon tidak diletakkan di tengah bangunan, maka para penjaga tidak dapat mengawasi tahanan secara menyeluruh dan tahanan yang tidak berada pada tempat yang terkontrol akan merasa luput dari pengawasan. Pemilihan lokasi prasasti-prasasti sapatha Sriwijaya juga dilatar belakangi oleh keterjangkauan kontrol. Maksudnya, prasasti harus diletakkan pada tempat yang strategis agar semua pihak yang berpikir untuk melakukan kejahatan atau berkhianat pada Sriwijaya dapat mengurungkan niatnya karena kesadaran tentang 'pengawasan' prasasti dan ancaman kutukan yang akan menimpa.

Unsur kutukan atau sapatha yang ada pada prasasti tertua Sriwijaya terdiri atas ancaman kutukan mati. Kutukan tersebut ditujukan kepada pihak-pihak yang melakukan kejahatan dan berkhianat kepada Sriwijaya. Pencantuman sapatha pada prasastiprasasti Sriwijaya dapat dianalisis sebagai bentuk upaya kontrol dari penguasa terhadap penduduk dan wilayah kekuasannya. Prasasti pada konteks panoptisisme dapat diartikan sebagai wakil penguasa dalam melaksanakan pengintaian di lokasilokasi strategis dan sapatha yang ada pada teks prasasti berfungsi sebagai pengintai kegiatan pihak yang dikuasai dan ancaman hukuman yang akan diterima pelanggar aturan penguasa Sriwijaya.

Prasasti sapatha selain dapat dikaji dalam perspektif panoptisisme 
juga dapat dijadikan dasar untuk menentukan pusat-pusat perdagangan pada masa Sriwijaya. Telaah terhadap masalah ini dapat dilakukan dalam cakupan satu prasasti dengan satu wilayah tertentu maupun semua prasasti secara keseluruhan dengan wilayah yang lebih luas. Selain itu, keberadaan prasasti-prasasti keagamaan dan prasasti politik Sriwijaya yang tidak dilengkapi dengan sapatha juga menarik untuk dikaji lebih lanjut guna merekontruksi kebesaran Sriwijaya dimasa lampau.

\section{DAFTAR PUSTAKA}

Andaya, L., Y. (2001). The Search of The 'Origin' of Melayu dalam Journal of Southeast Asian Studies, Vol. 32, No. 3, Halaman 315-330.

Bottenberg, W. R. (2010). Sriwijaya: Myth or Reality?. Tesis Magister Universiteit Leiden, tidak diterbitkan.

Foucault, M. (1995). Discipline and Punish: The Birth of the Prison. Diterjemahkan dalam Bahasa Inggris oleh Alan Sheridan. New York: Vintage Books.

Hardiati, E.S., Djafar, H., Soeroso, Ferdinandus, P.E.J. \& Nastiti, T.S. (2010). Sejarah Nasional Indonesia Jilid II: Zaman Kuno. Jakarta: Balai Pustaka.

Hardinanto, A. (2017) Autentisitas Sumber Sejarah Pancasila dalam Masa Sidang Pertama Badan Untuk Menyeledidi Usaha-usana
Persiapan Kemerdekaan Tanggal 29 Mei-1 Juni 1945 dalam Jurnal Veritas et Justitia, Vol 3, No. 1.

Izza, N., A. (2015). Bangka: Dalam Jejak Kejayaan Thalasokrasi Indonesia Kuno. Bangka: Dinas Kebudayaan dan Pariwisata Kabupaten Bangka.

Kanumoyoso, B. (2011). Beyond The City Hall: Society and Economic Development in the Ommelanden of Batavia, 1664-1740. Disertasi Universiteit Leiden, tidak diterbitkan.

Kartakusuma, R. (1993) Dapunta Hiyam Sri Jayanasa: Kajian Atas Makna Dari Prasasti Telaga Batu dalam Amerta Berkala Arkeologi, Nomor 13, Halaman 17-32.

Kern, H. (1913). Inscriptie van Kota Kapoer dalam Bijdragen tot de Taal-, Land- en Volkenkunde van Nederlandsch-Indië, Deel 67, Halaman 393-400. Leiden: Brill.

Kusno, A. (2007). Memory Keeper: Substation in Java City. Yogyakarta: Waves Publisher.

Mardiana, dkk. (2016). Prasasti Batu I: Pembacaan Ulang dan Alih Aksara. Jakarta: Museum Nasional Indonesia.

Mardiana, dkk. (2016). Prasasti Rajaraja Nusantara. Jakarta: Museum Nasional Indonesia.

Taim, E., A., P. (2013). Studi Kewilayahan dalam Penelitian Peradaban Sriwijaya. dalam Kalpataru Majapah Arkeologi, Vol. 22, No. 2, November 2013, Halaman 101-109.

Utomo, B., B. (2010) Atlas Sejarah Indonesia Masa Klasik (Hindu- 
Buddha). Jakarta: Kementerian Kebudayaan dan Pariwisata, Direktorat Jenderal Sejarah dan Purbakala, Direktorat Geografi Sejarah.

Williams, M. S. (1964). EnglishSanskrit Dictionary. Delhi: Motilal Banarsidass.

Foto Prasasti Kota Kapur diambil dari www.digitalcollections.universitei tleiden.nl diakses pada $26 \mathrm{Mei}$ 2019. 